The Comparative Advantage of Government

Why should governments be involved in the provision of any good whatsoever?

A Review

Pedro Belli

The World Bank

Operational Core Services Network

Operational Services Team

October 1997 
Policy Research Working Paper 1834

\section{Summary findings}

In theory, market failures are necessary but not sufficient conditions for justifying government intervention in the production of goods and services. Even without market failures, there might be a case for government intervention on the grounds of poverty reduction or merit goods (for example, mandatory elementary education and mandatory use of seatbelts in cars and of helmets on motorbikes)

In every case, contends Belli, a case for government intervention must first identify the particular market failure that prevents the private sector from producing the socially optimal quantity of the good or service. Second, it must select the intervention that will most improve welfare. Third, it must show that society will be better off as a result of government involvement - must show that the benefits will outweigh the costs.

It is impossible to judge a priori whether or what type of government intervention is appropriate to a particular circumstance or even to a class of situations. Such judgments are both country-and situation-specific and must be made on a case-by-case basis.

To be sure, it is easier to make such judgments about market failures based on externalities, public goods, and so on, than about the market failures based on imperfect information. Market failures rooted in incomplete markets and imperfect information are pervasive: Markets are almost always incomplete, and information is always imperfect.

This does not mean that there is always a case for government intervention and that further analysis is unnecessary. On the contrary, there is a keener need for analysis. The welfare consequences of the "new market failures" are more difficult to measure so government intervention's contribution to welfare is likely to be more difficult to assess and the case for intervention (especially the provision of goods and services) is more difficult to make.

One must also keep in mind that government interventions are often poorly designed and overcostly. Poorly designed interventions may create market failures of their own. Governments concerned about low private investment in high-risk projects, for example, may guarantee them against risk but in the process create problems of moral hazard and induce investors to take no actions to mitigate such risks.

And some interventions may turn out to be too costly relative to the posited benefits. In seeking to provide extension services, for example, governments may incur costs that are higher than the benefits farmers receive.

This paper - a product of the Operational Services Team, Operational Core Services Network — is part of a larger effort in the Bank to improve economic analysis. Copies of the paper are available free from the World Bank, $1818 \mathrm{H}$ Street NW, Washington, DC 20433. Please contact Luis Schunk, room MC10-360, telephone 202-473-1779, fax 202-522-3253, Internet address lschunk@worldbank.org. October 1997. (16 pages)

The Policy Research Working Paper Series disseminates the findings of work in progress to encourage the exchange of ideas about development issues. An objective of the series is to get the findings out quickly, even if the presentations are less than fully polished. The papers carry the names of the authors and should be cited accordingly. The findings, interpretations, and conclusions expressed in this paper are entirely those of the authors. They do not necessarily represent the view of the World Bank, its Executive Directors, or the countries they represent. 


\section{The Comparative Advantage of Government:}

A Review

Pedro Belli 



\title{
The Comparative Advantage of Government: A Review
}

\author{
The important thing for government is not to do things which \\ individuals are doing already and to do them a little better or a \\ little worse: but to do those things which are not done at all.
}

\section{J. M. Keynes, "The End of Laissez-Faire"}

1. Worldwide, the private sector is increasingly providing goods and services that a few decades ago were deemed to be properly in the domain of the public sector. Several reasons account for the shrinking role of government in this regard. First, the economic development paradigm no longer considers it appropriate for governments to act as entrepreneurs. Second, an inconclusive, albeit growing, body of evidence indicates that the public sector tends to use funds less efficiently than the private sector when engaged in market-oriented activities. 1 Third, technological changes are making it possible to bave competition in markets that traditionally have been considered natural monopolies. Is there still a justification for public provision of goods and services, or should the private sector be the sole provider?

2. The economic answer depends partially on whether a country's welfare is likely to increase more if the public rather than the private sector is the provider. In turn, this depends on a host of conditions that vary from country to country and, within a particular country, from year to year: for example, institutional arrangements; legal, regulatory, and political conditions; and external circumstances. In addition to economic considerations, there are distributional, political and strategic considerations. Consequently, there are no hard and fast rules by which to conclude unmistakably that one or the other sector is the appropriate provider-in the end this decision is largely a matter of judgment. 2 This paper reviews the main arguments for public intervention in the provision of goods and services and shows how the traditional tools of economic analysis of projects can shed light on this important question.

\section{General Considerations}

3. Why should governments be involved in the provision of any good whatsoever? As far back as 1776, Adam Smith argued in The Wealth of Nations that in competitive markets, an individual pursuing private gains would promote the common good:

He intends only his own gain, and he is in this, as in many other cases, led by an invisible hand to promote an end which was no part of his intention. Nor is it always the worse for society that it was no part of it. By pursuing his own interest he frequently promotes that of the society more effectually than when he really intends to promote it.

1 There are no theoretical grounds for supposing that private sector enterprises are more efficient than public enterprises, nor is there conclusive evidence showing that one is more efficient than the other. Examples of efficiency and inefficiency can be found in both sectors. Yet even those economists who make strong cases for government intervention side with the popular notion that public enterprises are less efficient (see, for example, Stiglitz, 1994, p. 237).

2 In the context of Bank work, the initial justification for public provision ought to stem from an analysis of the country's public expenditure program and, should be justified in the Country Assistance Strategy. 
In the 1950s Arrow (1951a) and Debreu (1959) formalized Adam Smith's insight in what are now known as the two fundamental theorems of welfare economics. The first theorem says that under certain conditions every competitive equilibrium is Pareto-efficient - that is, in an economy that reaches a competitive equilibrium, no one can be made better off without making someone else worse off. The second theorem says that under certain conditions every Paretoefficient allocation of resources can be obtained through a decentralized market mechanism. These theorems are relevant to any discussion of the role of government in resource allocation: they imply that under the conditions assumed by Arrow and Debreu, no government or central planner, however omniscient and well-intentioned, can improve on the results obtained by the free market system. The best of all possible planners might do as well as competitive firms attempting to maximize their own profits, but they would never do better. This point is especially relevant for project analysis because under the ideal conditions posited by Arrow and Debreu, a project's net benefits from an investor's perspective would give an exact measure of the net benefits from society's perspective. The economic and financial evaluation of a project would yield exactly the same result.

4. If the real world fulfilled the assumptions of the fundamental theorems of welfare economics, the market would produce every good in demand and there would be no need for governments to provide any good or service. Equity considerations, then, would be the only economic justification for government intervention. However, the real world, is a far cry from the idealized Arrow-Debreu world. In many cases private markets fail to produce the socially optimal quantities of goods and services and, in principle, government intervention can enhance welfare.

5. Market failures (departures from the ideal conditions posited by Arrow and Debreu) occur because (a) competition is imperfect (someone may have monopoly power, for example); (b) producers may impose a cost or confer a benefit to other producers (or consumers) without paying for the cost or charging for the benefit (that is, there are externalities); (c) the process produces a "public good" for which it is impossible or undesirable to levy a charge; (d) markets are incomplete (they do not extend infinitely far into the future and they do not cover all risks); or (e) information is incomplete and imperfect. There is an a priori rationale for public sector involvement whenever the market cannot or will not produce the socially desirable quantity of the good or service. But the public sector should be the residual provider of goods, intervening only when the market does not produce the socially optimal quantity of the good or service.

6. The nature of government involvement, however, merits careful consideration. In some cases it may be appropriate for the government to produce goods (roads, for example); in others, financing production of the service might be just more advisable (primary education, for example); in yet others, a subsidy might be the most suitable intervention (subsidizing a forest that sequesters carbon dioxide, or the access of poor people to safe water, for example). In all cases, the analyst must ask three fundamental questions: (a) What market failure leads the private sector to produce more or less than the socially optimal quantity of this good or service? (b) What sort of government intervention is appropriate to ensure that the optimal quantity is produced? and (c) Is the recommended government intervention likely to have the desired impact? If there is a strong case for government intervention, we must assess the costs and benefits of government involvement and show that the benefits are likely to outweigh the costs. We cannot assume that government bureaucrats will succeed where markets fail. Government interventions, often poorly designed and implemented, may create more problems than they solve. The rest of this paper will review some of the most common market failures and the rationale for public intervention in each case. At the end of the paper we will also discuss two 
reasons for government intervention, merit goods and poverty reduction, that are separate from market failures.

\section{Market Failures}

\section{Natural Monopolies}

7. Natural monopolies provide one of the oldest justifications for government provision of goods and services. Adam Smith's invisible hand works well only in competitive markets. In many markets competition does not exist, and in others competition is inefficient. Some production processes enjoy economies of scale; that is, unit costs of production fall as output rises. A common example is the supply of electricity: in densely populated regions, it is more efficient to supply electricity through an integrated network than for every household to have its own generator. When economies of scale are present, large firms produce more cheaply than small firms and tend to dominate their markets; eventually they may drive smaller firms into bankruptcy and, in extreme cases, may become monopolies. Industries in which the conditions of demand and supply are such that production by a single firm minimizes costs are known as a natural monopolies. Unregulated monopolies of any kind, natural or not, tend to charge too much and produce too little. Whenever natural monopolies are present, government intervention, at least in principle, can lead to more production at a lower price.

8. What kind of intervention is appropriate? The first alternative is to do nothing. This solution might be optimal when the product or service has close substitutes and monopoly power is weak, that is, when the ability to charge prices that result in excess profits is insignificant. In the case of cable television, for example, the presence of close substitutes reduces the monopoly power of cable providers enough to obviate government intervention. Before deciding that some form of government intervention is called for, we need to assess the welfare losses from the exercise of monopoly power. For a methodology for estimating the welfare losses from monopoly, see Harberger's (1954) seminal article, and the extension by Cowling and Mueller (1978). Ferguson (1988) provides a summary of several studies on the subject.3

9. The traditional solution in many countries has been to have a public enterprise provide the good or service. In many countries electricity is publicly provided, and many water companies around the world are public enterprises. The assumption has been that a public enterprise would maximize social rather than private welfare. To induce public enterprises to maximize social welfare is extremely difficult because social welfare is tough to measure and hence so is the performance of managers of public enterprises. Therefore, we must usually use proxies that at best are imperfect substitutes. As a result, what managers of public enterprises maximize is not necessarily welfare, but something else. Peltzman (1971) postulated that managers of public enterprises maximize political support. His theory predicts that public enterprises will set a price below the profit-maximizing price, voters will pay lower prices than nonvoters, and public enterprises will use less price discrimination than private firms. Evidence from developed countries supports Peltzman's theory and shows that public enterprises tend to charge lower prices than regulated private monopolies, practice less price discrimination, and adjust rates less frequently (Peltzman, 1971, Moore 1970).

3 It should be noted that technological advances are making it possible to have competitive markets in areas that in the past were considered natural monopolies (telecommunications, for example). 
10. Another traditional solution has been to have a private, but regulated, enterprise provide the good or service. In some countries, telephone companies are private, regulated monopolies. Regulation itself has benefits and costs. The benefits are the reduction in deadweight losses in efficiency that would exist under monopoly. The costs include the direct costs of regulatory agencies, higher production costs because of changed incentives for regulated firms, and unintended side effects of regulation. For regulation to be effective, the regulatory agency must induce the firm to provide the good or service at average cost pricing, which in turn requires that it have cost and demand information. For a discussion of the costs and benefits of regulation, see Viscusi, Vernon, and Harrington (1966).

11. A solution that is becoming more common is to auction off the franchise to private firms. The franchise is awarded via competitive bidding to the firm that offers to provide a given quality of service at the lowest price. In theory, a large number of bidders drives the price down to the point where the eventual provider earns a normal return. Franchise bidding should thus avoid the need for regulation while achieving the same result. In practice, franchise bidding has been much more complex, and it is not at all clear that it has generated socially desirable solutions. Viscusi, Vernon, and Harrington (1996) provide a good review of experience in the United States.

12. Which is the preferred solution for dealing with natural monopolies-a regulated private firm, a public enterprise, or franchise bidding? It is difficult to rank the alternatives in order of preference. The evidence concerning the relative efficiency of regulated privately owned utilities compared to public utilities is mixed, though the weight of the evidence points to greater efficiency in regulated private enterprises (Moore, 1970; DiLorenzo and Robinson, 1982). The experience with franchise bidding in the United States indicates that government quickly turns from mere auctioneer to regulator. Nevertheless, because franchise bidding provides a greater role for competitive forces, it is the most promising.

\section{Externalities}

13. Externalities provide another traditional argument for government intervention.

Sometimes activities generate benefits and costs that are not reflected in the benefits and costs of the firm. A forest, for example, may lower the level of carbon dioxide in the world, but the owner of the forest-who bears the full cost of planting and maintaining the forest-cannot charge for this benefit. As a result, the forest may be smaller than desirable from the world's point of view. In some other cases, a project may use resources for which it does not pay. Consequently it may produce more than is socially desirable. An irrigation project, for example, may lead to reduced fish catch downstream. The project's effect on the downstream fisheries are costs to society that are not reflected in the project's accounts. This discrepancy between private and social costs leads to a larger scale of irrigation than is socially desirable. Externalities are among the principal justifications given for public involvement in the provision of education services and prevention of communicable diseases.

14. Government can intervene in various ways to induce firms to produce the socially optimal quantity of goods whose production process is subject to externalities. Again, if the magnitude of the externality is insignificant one alternative is to do nothing. Automobiles have been polluting the air since they were invented, but the problem did not become serious until automobiles became numerous. Another solution is to regulate. The Clean Air Act in the United States, for example, sets ambient quality standards irrespective of cost considerations. A third solution is to tax the producer of negative externalities to discourage their production and to 
subsidize the producer of positive externalities to encourage their production. The Global Environmental Facility funds production of goods and services that reduce global environmental externalities, for example.

15 Conceptually, at least, optimal solutions can be reached through taxes and subsidies. Figure 1 shows the market for good $\mathrm{X}$. The production of this good is subject to an externality that increases the social cost of production (SMC) above the private cost (PMC). The marginal benefit of good $\mathrm{X}$ is given by the demand curve. Without government intervention, the market will produce $\mathrm{Q}$ units as compared to the optimal quantity $\mathrm{Q}^{*}$ and the optimal price $\mathrm{P}^{*}$. An optimal tax equal to $\mathrm{P}^{*}$ - $\mathrm{P}$ would raise the price of $\mathrm{X}$ to $\mathrm{P}^{*}$ and induce production of $\mathrm{Q}^{*}$ units. Instead of a tax, the government could impose a quota to limit production of $X$ to $\mathrm{Q}^{*}$ units. Eventually the market will drive the price of $X$ up to $P^{*}$. Government could also intervene by producing good $\mathrm{X}$ and limiting its output to $\mathrm{Q}^{*}$. If the externality were positive, the position of the SMC and PMC would be reversed and the optimal intervention would be a subsidy.

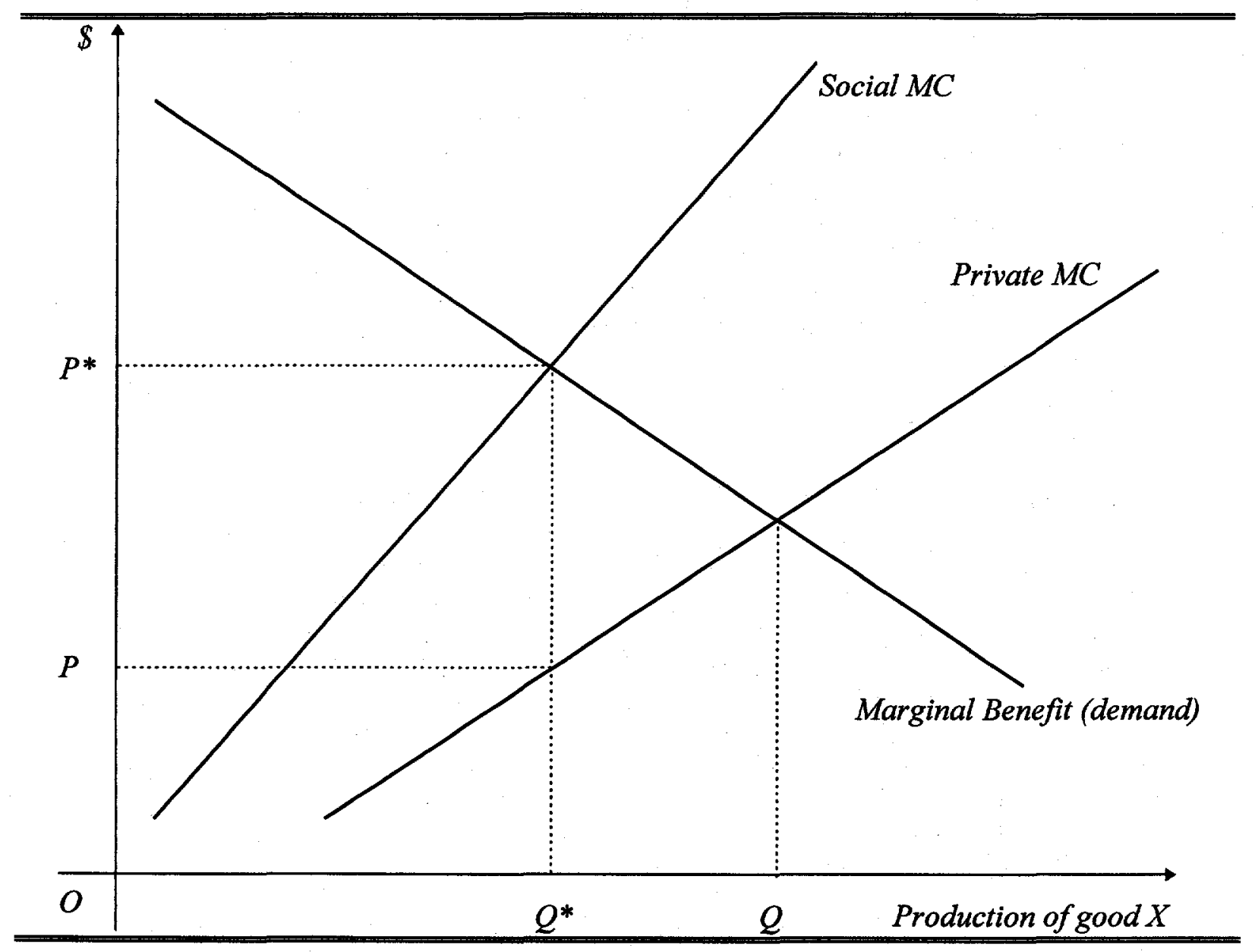

Figure 1. MARKET SOLUTION VS. SOCIAL OPTIMUM WHEN EXTERNALITIES ARE PRESENT

\section{Public Goods}

16. The third traditional argument for public provision concerns the nature of the goods and services themselves. All goods provided by the private sector share one important feature, 
namely, that the provider of the good can charge those who wish to consume it and make a profit in the process. Not all goods, however, share this characteristic. There is a broad category of goods called public goods for which it is either impossible or undesirable to charge. The private sector usually shies away from producing public goods; or if it does produce them, it usually charges too much and produces too little of them. For example, cleaning up the air in Mexico City would be of great benefit to the city, but no private sector company would do it because it could not charge for the service.

17. Exclusion difficult or costly. Some public goods are not produced by private markets because it is impossible to prevent anyone from consuming them, even if they do not want to pay for them. These public goods are called nonexcludable goods. Consider national defense. If an army succeeds in defending the national territory against an enemy, every citizen benefits, whether he/she paid to sustain the army or not. Similarly, spraying an area to rid it of malariacarrying mosquitoes benefits every nearby inhabitant, but it is difficult, to charge everyone for the service. Those who refuse to pay for spraying will get a free ride. If a sufficiently large number refuse to pay, spraying may not take place. Because of these difficulties, the private sector will not usually produce nonexcludable public goods (or will produce suboptimal quantities). Public production of nonexcludable public goods has been considered to enhance public welfare and therefore to be a proper function of government.

18. In some cases exclusion is possible, but costly. Roads are nonexcludable, but toll roads are excludable. The costs associated with limited-access roads, however, are considerably higher than those of normal roads: exclusion comes at a high cost. Whenever a project produces a good for which the cost of exclusion is high, there is also a strong presumption for public provision.

19. Nonrival goods (exclusion undesirable or inefficient). Private goods also share another important characteristic, namely that the marginal cost of consumption is high. In the case of nonrival public goods, however, the marginal cost of consumption is zero or very low. Although private production of nonrival goods is possible, the private sector will produce suboptimal quantities. Socially optimal pricing requires that the price of goods or services be equal to the marginal cost of consumption. If the price is set to equal marginal cost, private provision may be unprofitable. Once a bridge is built, for example, the marginal cost of letting another car use it is virtually zero (up to the point of congestion). For an uncongested bridge, optimal pricing would require a very low toll, too low to recover the initial investment and hence too low to interest the private sector. If the toll were set high enough to interest the private sector, too few cars would use the bridge. Likewise, the cost of informing one thousand consumers over the air waves is the same as the cost of informing two thousand, and the information available to a thousand additional consumers does not reduce the amount available to others: the marginal cost of consumption is zero. Whenever the marginal cost of consumption is zero or extremely low, it is undesirable to use the price system to ration the good, as efficiency requires that goods and services be provided at the marginal cost of providing them. The private sector, which would charge more than the marginal cost of provision, would provide suboptimal amounts of these goods. Low marginal cost of consumption is often used as an argument for public provision of research and extension, utility services, and public information services (agricultural prices and weather patterns). The argument for public involvement in the provision of nonrival public goods is strong, but the nature of the involvement need not be provision of the good, as provision of funding may be optimal in many cases. For example, the optimal quantity of research and extension services may be achieved with public funding of private provision.

20. Some goods are both nonexcludable and nonrival. National defense, for example, is both nonexcludable and nonrival: the cost of protecting a given territory against foreign invaders is 
the same, whether the inhabitants of the territory amount to one or two million. Pure public goods are both nonexcludable and nonrival. Private goods, say shoes, are both excludable and rival. In between these two extremes, there is a host of goods that may be only partially nonexcludable or partially nonrival. Information and technology, for example, are nonrival and partially nonexcludable goods. The provider of pure public goods incurs all the costs but reaps none of the benefits, the provider of private goods incurs all of the costs and (except for taxes) reaps all of the benefits. 1 As general rule, there is no economic justification for public provision of private goods in competitive markets.

21. Figure 2 shows the ease of exclusion along the horizontal axis and the cost of exclusion (marginal cost of consumption) on the vertical axis. Pure public goods appear in the lower lefthand corner. These goods are nonexcludable and nonrival. Pure private goods appear in the upper right-hand corner, where the marginal cost of consumption is equal, or nearly equal, to the average cost, and the cost of exclusion is low. Impure public goods are only partially excludable or partially nonrival. A bridge is an example of an impure public good. Once built, it is relatively simple to exclude anyone from using it, but because the marginal cost of an additional automobile crossing is low (up to the point of congestion), it is not socially desirable to charge a fee that exceeds the marginal cost. A crowded limited-access highway is an example where exclusion is easy, but where the marginal social cost of a vehicle entering might be very high.

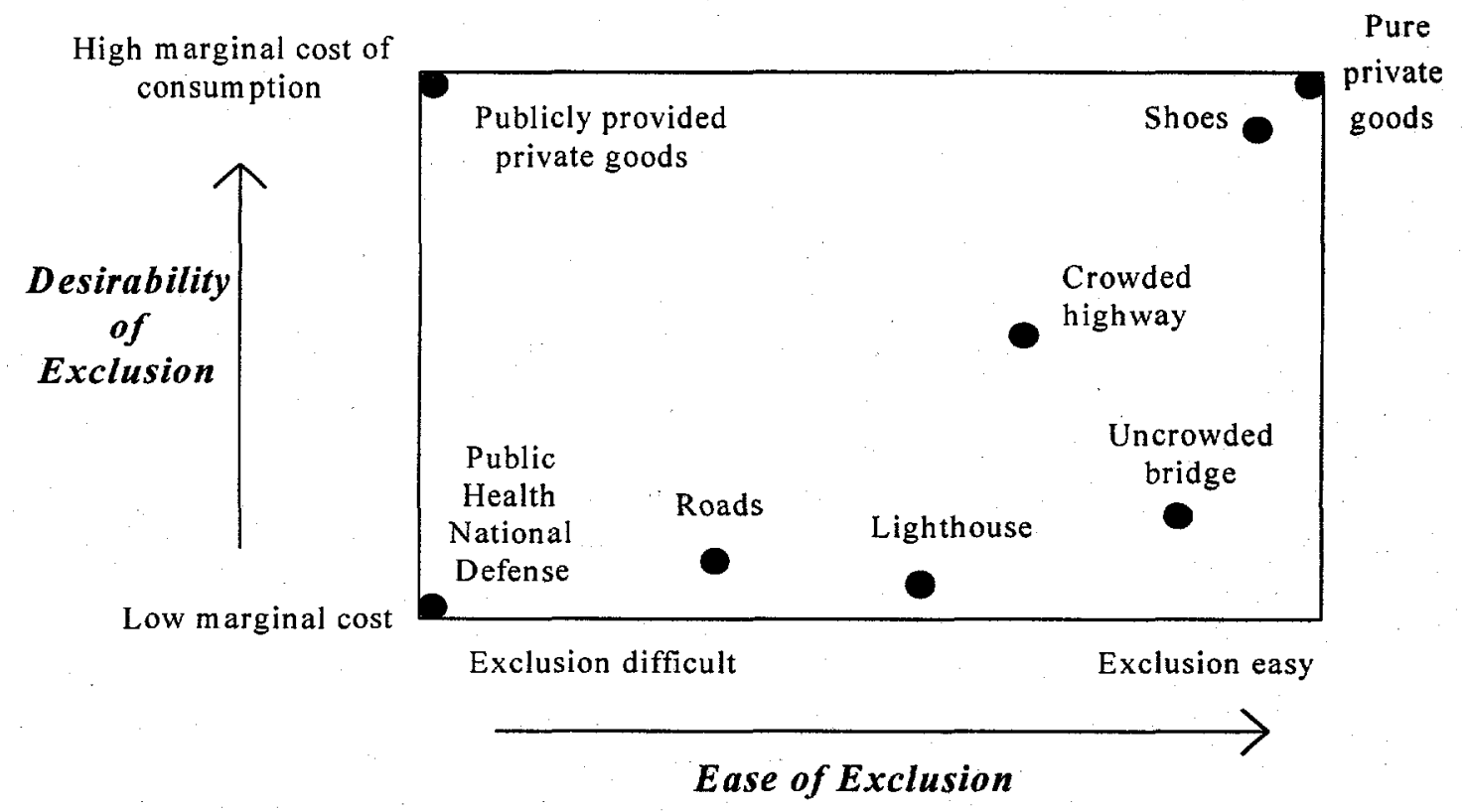

Figure 2: PURE IMPURE PUBLIC GOODS 5

4 That is, only if the production of the good is not subject to externalities.

5 After Stiglitz (1988). 
22. Many Bank projects finance public goods. A difference between a project that produces private goods and one that produces public goods is the distribution of costs and benefits among various groups in society. In the case of private goods, the benefits (save for taxes) as well as the costs accrue to the project entity. In the case of public goods, the project entity incurs the costs but society at large enjoys the benefits.

23. The very nature of public goods implies that there are no markets for them, and hence it is difficult to value the benefits of producing them. As the Bank's business moves away from financing the production of private goods to financing the production of public goods, the traditional tools of economic analysis need to be extended to evaluate the benefits of goods and services for which there are no ready markets. In some cases (roads, for example) the tools are well developed, in other cases (health, for example) they are controversial, and in yet others (environment) they are rudimentary. Table 1 shows in schematic form a hypothetical distribution of costs and benefits for a pure public good.

Table 1: Hypothetical Distribution of Costs and Benefits of a Public Good

\begin{tabular}{lcccc}
\hline \hline & Project Entity & Government & Others & Society \\
\hline Benefits & 0 & 0 & 150 & 150 \\
Costs & $(80)$ & 0 & & $(80)$ \\
Net benefits & $(80)$ & 0 & 150 & 70 \\
Subsidies & 80 & $(80)$ & 0 & 0 \\
$\quad$ Total & 0 & $(80)$ & 150 & 70 \\
\hline \hline
\end{tabular}

24. In this case the provider incurs all of the costs but does not receive a monetary reward for any of the benefits because it cannot charge for them. The benefits accrue to the country at large, or "others." The provider needs to be subsidized to survive and as a result there is a negative fiscal impact of 80 . As the last column shows, the project generates gross benefits of 150 and net benefits of 70 . Note that if the project produced a private good, the economic costs and benefits would be exactly alike. What would differ would be the distribution of benefits and costs among the various groups in society. If we looked only at the last column, we would not be able to tell whether the good is public or private.

25. By exploiting the information embedded in the differences between private and social prices and private and social flows, the tools of economic analysis of projects enable us to construct tables showing the distribution of costs and benefits. They thus provide very valuable information that can guide the decision to place a project in the public or in the private sector. For an application of these techniques, see Belli, Anderson, Barnum, Dixon, and Tan, 1996.

\section{Asymmetric Information and Incomplete Markets}

26. Perfect information, equally shared among all consumers and producers, is a basic assumption of the two fundamental theorems of welfare economics. Another basic assumption is the existence of complete markets (a market for every type of good and service, for every type of risk, extending forever into the future). Neither of these assumptions is ever fulfilled.

Information is always imperfect, and markets seldom provide all goods and services for which the cost of provision is less than what individuals are willing to pay. When information is imperfect and markets are incomplete, the actions of individuals have externality-like effects that result in suboptimal production of goods and services (Greenwald and Stiglitz, 1986). 
Information-based market failures differ from the market failures discussed above in two important respects. First, for the most part, the former or "older" market failures are related to an easily identifiable source, and second, they can be corrected (at least conceptually) with welldefined government interventions. Market failures based on imperfect and costly information and incomplete markets, on the other hand, are pervasive in the economy and difficult (if not impossible) to correct, as nearly all markets are incomplete and information is always imperfect. Full corrective policy would be impractical as it would entail taxes and subsidies on virtually all commodities. We now consider some arguments for public intervention when information is imperfect and markets are incomplete.

27. Ignorant consumers and informed producers. Parties to market transactions rarely share the same information. Producers usually know more than consumers do about the product they are selling. Bank managers and bank owners, for example, know more about the financial health of their institutions than consumers do. Buyers of used cars usually know less about the car than the owner and may get stuck with a lemon. Patients usually know less about how to treat a disease than their doctor and will accept the treatment prescribed, even if there is no need for it. Asymmetric information is pervasive. If information were complete and equally shared, more transactions would take place as fewer parties would fear "being taken." Government interventions that improve information flows can lead to more transactions and hence to increased welfare. Although in principle taxes and subsidies would lead to optimal allocation of resources and hence to improved welfare, in practice most interventions aiming at correcting information failures do not rely on taxes and subsidies, but on the coercive power of government. Thus, in many countries banks are required to disclose financial information, sellers are required to disclose information about the goods they are selling to potential buyers, and there are strict disclosure requirements for publicly traded stocks.

28. Informed consumers and ignorant producers. Asymmetric information also works against producers. It is often argued, for example, that lack of information induces lenders not to lend to certain groups, or lend at rates that cover not only costs and risks but also the lack of information. Hence, they lend less than the social optimum. If information about the borrowers were better, it is often argued, lenders would be willing to lend at lower rates and hence would attract more clients.

29. The World Bank is an example of an intervention that improves information and capital markets. By virtue of its charter, the World Bank has access to information about its borrowers that commercial banks do not and therefore it can assess country risks better than a commercial bank. Because it can also influence policy, it can diminish country risks and improve the flows of private capital into developing countries. The Grameen Bank in Bangladesh is an example of an intervention that completes an incomplete capital market. This rural bank was created to provide credit and organizational support to individuals who, for lack of material collateral, would be excluded from the formal credit system. The Grameen Bank tackles the problem of asymmetric information by lending only to small groups of self-selected individuals who are known to one another and who monitor and provide the repayment guarantees for each other. It tackles the enforcement problem by linking the individual's continued access to credit to the group's repayment record. Among other things, its proximity to its clients facilitates the flow of information, which in turn enables it to supplement an incomplete market and improve its efficiency.

30. The rationale for public intervention in activities that provide information is strong. Stiglitz (1988), argues that in many ways, information is a public good. First, it is nonrival, as giving information to one more individual does not reduce the amount available to others. 
Second, it is largely nonexcludable, as the marginal cost of giving information to one more individual is low and at most equal to the cost of transmitting the information. Efficiency requires that information be given at the marginal cost of providing it. Because the marginal costs of provision may be close to zero, the private sector, which charges more than the marginal cost, often provides too little information. Although the case for public intervention in the provision of information is strong, the rationale for public provision of information is weaker. Publicly funded tornado warning services, for example, may be provided over private radio stations; they need not be provided over public radio stations.

31. Asymmetric information gives rise to adverse selection and moral hazard, two problems that arise in a variety of contexts, but that are most clearly seen in the case of insurance markets. With either problem, private markets tend to provide too little of a good or service, and appropriate government intervention can enhance welfare.

32. Adverse selection. It is human nature to seek protection when we are at risk and to be less careful when we are not at risk. In any given population, some people are at higher risk than others with respect to a certain event. Residents of California are at higher risk from earthquake damage than residents of Virginia. As a result, Californians generally buy earthquake insurance and Virginians do not. If everyone in the United States purchased earthquake insurance, rates would be lower. But buyers of insurance are not necessarily randomly selected. They are selfselected: only those who consider themselves at risk buy insurance. From an insurance company's viewpoint, buyers are adversely self-selected. As a result, insurance companies charge higher premiums than they would if the selection were random. Higher premiums lead to thinner markets. Whenever the insurance premiums are set so high as to compensate for adverse selection, large numbers of people who would be willing to pay for the actuarially fair rate to protect themselves from a particular risk do not buy insurance. Adverse selection has been cited as a justification for public intervention in, for example, the health sector. As a result of adverse selection and ensuing high insurance premiums, many people may be left without insurance against catastrophic illness, leading to large discrepancies between social and private benefits (Hammer, 1996).

33. Moral hazard. It is also human nature to be less careful when we do not have to suffer the consequences of our own actions. Thus, we tend to speed if there is no fear of being caught. Banks that are insured by the government against bad loans may not exercise as much care as banks that incur the full cost of bad loans gone sour. Likewise, people who are insured against theft may be less careful with their belongings than those who are not insured. The lack of incentive to take care when we do not have to suffer the consequences of our own actions is called moral hazard. In markets where moral hazard is present, too little of a certain good is typically offered. For example, consumers would like to buy more insurance, and insurance companies to sell it - - but only if consumers exercise due care. However, insurance companies, cannot be sure that consumers will exercise due care, and therefore they sell less insurance than consumers are willing to buy: they ask consumers to bear some of the risk, that is, to self-insure and to copay. Many authors think that moral hazard problems are not a good justification for public intervention (see, for example, Lal, 1994, and Varian, 1987), but rather a limitation of the extent of insurance that can be provided. But Greenwald and Stiglitz (1986) have shown that, in theory, if moral hazard problems are present, governments can effect Pareto improvements by taxing and subsidizing various commodities that induce people to take greater care. For example, by subsidizing the use of seatbelts, the government can encourage drivers to exercise greater care, and by taxing cigarettes and alcohol, it can discourage smoking in bed in a state of 
inebriation and therefore reduce the incidence of fires. Government provision of information can have effects on incentives akin to those of taxes and subsidies.

34. Risk aversion. The public sector, as representative of a country's entire population, can spread risk over every citizen in the country and is therefore in a unique position as an investor. For this reason, Arrow and Lind (1970) argued that when governments act as investors, they should be risk-neutral, that is neither prefer nor avoid risk. Governments, Arrow and Lind argued, should normally choose projects on the basis of their expected net present value and disregard the variance around the mean of the net present value. For private investors, who are normally risk-averse, there is always a trade-off between risk and return, often expressed as a trade-off between the variance and the mean. If problems of moral hazard did not exist and insurance markets were complete, private investors would be able to buy insurance against commercial failure and undertake riskier projects. But investors cannot insure against commercial failure and normally shy away from excessively risky projects. The absence of an insurance market against commercial failure and government risk neutrality imply that some risky projects may be attractive to the public sector but not to the private sector (Arrow and Lind, 1970). If a project is not attractive to the private sector because it is too risky, public provision may be justified, even if the project produces a private good.

35. Complementary Markets. In some cases, the production of a good requires the production of a complementary good-computers and computer programs, for example. Software companies flourished only after the advent of personal computers. This example of complementary markets involves only two goods. In some cases, many markets-and large scale coordination-must be involved. Public intervention in urban renewal programs and rural development have been justified on the grounds of this market failure. The renewal of a large section of a city or the development of rural areas requires extensive coordination among many actors, including factories, retailers, landlords, transport, and so on. Similarly the development of rural areas requires extensive coordination among various actors. If markets were complete, the coordination would take place through the price system. Incomplete markets require that someone act as coordinator.

36. Cost of Capital. In a perfect and undistorted capital market, the market rate of interest would reflect the cost of capital to a country: on the demand side, the market rate of interest would be equal to the marginal productivity of capital, and on the supply side, it would be equal to the rate of time preference for consumption. Taxes, however, drive a wedge between the private and the social opportunity cost of capital. On the demand side, the private after-tax return is lower than the social return, that is, lower than the marginal productivity of capital in the private sector. On the supply side, also because of taxes, the marginal return to savers is lower than the social return, that is, lower than the rate of time preference for consumption. The cost of capital to the public sector then, viewed as the weighted average of the social marginal productivity of capital in the private sector and the social rate of time preference for consumption, is usually higher than the private cost of capital. Under certain circumstances, however, the cost of capital to the private sector might be higher than the cost of capital to society. For example, the public sector may have access to low-cost sources of funds, say IDA, while the private sector may not. When the private sector looks at a project, therefore, it may use a higher discount rate than the public sector and reject projects with, for example, long gestation periods. For these reasons, some projects that may be highly beneficial to society may not be attractive to private investors. In these cases, government intervention, through provision or subsidies, can improve welfare. 
37. Size of the Project. The size and strategic nature of the project may be another justification for public provision. The public sector, as the representative of a country's entire population, can command more resources than any single private sector entity and can thus undertake large, strategic projects that require capital investments that are beyond the financial reach of the private sector. Sometimes large projects may be attractive to foreign investors, but many countries are reluctant to allow foreign ownership of strategic resources. Public provision may be justified even if the project produces a private good, when the nature and size of the project are such that the domestic private sector would not be able to undertake it.

\section{Other Grounds for Public Intervention}

\section{Poverty Reduction}

38. Public intervention to reduce poverty may be justified on ethical and political grounds. Even in the idealized Arrow-Debreu world, Pareto-efficient solutions achieved by the decentralized market system depend upon the initial allocation of resources among all the actors in society. It would be entirely possible for a Pareto-efficient solution to be glaringly inequitable, leaving some with "too much" and others with "too little." In most countries the distribution of resources is unacceptable, and in some it is politically unsustainable. A case can be made for public provision of goods that the poor consume relatively more of than the nonpoor-that is, for goods with low income elasticity-on grounds of redistribution. Some types of health care may qualify. But low income elasticity is not the only grounds for government intervention in the provision of goods and services for the poor: many types of health and education services, that have high income elasticity, are provided to the poor on grounds of redistribution. Moreover, sometimes leakage is either technically inescapable or the political price of poverty reduction: to benefit the poor it may be necessary to benefit some of the nonpoor. Nevertheless, if poverty reduction is given as a rationale for public provision of any good or service, it is often desirable to target project benefits towards the poor.

\section{Merit Goods}

39. Another argument for government intervention even in the absence of market failures arises from the belief that individuals may not always act in their own best interest, and the government must intervene to see to it that they do. Mandatory use of seatbelts in cars and of helmets for motorbikers and mandatory elementary education are examples of a class of goods known as merit goods. The paternalistic argument for government intervention is different from the externalities and information arguments discussed above. Bikers may know the benefits of wearing helmets, yet may continue to ride without them. Those who advocate government intervention believe that it is not enough to provide information and force those who "misbehave" to pay for any externalities through taxation. As Stiglitz (1988) states, "Those who take the paternalistic view might argue that individuals should not be allowed to smoke, even in the privacy of their own homes, and even if a tax, which makes the smokers take account of the external costs imposed on others, is levied. This paternalistic role undoubtedly has been important in a number of areas, such as government policies toward drugs (marijuana) and liquor (prohibition), as well as compulsory education."

40. Using the merit goods argument for justifying government intervention is very delicate and controversial. Many economists believe that no group has the right to impose its will on another group. Moreover, they fear that special interest groups will attempt to use the 
government to further their own views about how individuals should act or what they should consume.

\section{Summary}

41. In theory, market failures are necessary but not sufficient conditions for justifying government intervention in the production of goods and services. Even in the absence of market failures, there might be a case for government intervention on grounds of poverty reduction and merit goods.

42. In every case, a case for government intervention must first identify the particular market failure that prevents the private sector from producing the socially optimal quantity of the good or service, second, it must select the intervention that will most improve welfare, and third, it must show that society will be better off as a result of government involvement; that is, it must assess the costs and benefits of government involvement and show that the benefits will outweigh the costs. Table 2 lists the most common rationales giving for public intervention and the types of interventions most commonly used.

43. It is impossible to judge a priori whether or what type of government intervention is appropriate to a particular circumstance or even to a class of situations. Such judgments are both country- and situation-specific and must be made on a case-by-case basis. To be sure, it is easier to make such judgments in the case of the old market failures than in the case of the new ones. Market failures rooted in incomplete markets and imperfect information are pervasive: markets are almost always incomplete and information is always imperfect. This does not mean that there is always a case for government intervention and that no more analysis is needed. On the contrary, there is a keener need for analysis. The welfare consequences of the "new market failures" are more difficult to measure. Therefore, the contribution of government interventions to welfare is likely to be more difficult to assess and the case for intervention (especially provision) more difficult to make.

44. It is important to keep in mind that government interventions are often poorly designed and excessively costly. Poorly designed interventions may create market failures of their own. For example, governments concerned about low private investment in high-risk projects may guarantee them against risk, but in the process create problems of moral hazard and induce investors to take no actions to mitigate such risks. Some interventions may turn out to be too costly relative to the posited benefits. In seeking to provide extension services, for example, governments may incur costs that are higher than the benefits received by farmers. 
Table 2: Rationale for and Examples of Public Interventions

\begin{tabular}{ll}
\hline Rationale & Examples of Intervention \\
\hline Natural monopolies & Franchise bidding, regulation, provision \\
Externalities & Taxes and subsidies, regulation, provision \\
Public goods & \\
$\quad$ Exclusion difficult & Provision \\
$\quad$ Exclusion undesirable & Subsidies, provision \\
Information failures & Regulation, taxes and subsidies, provision \\
Incomplete markets & Provision, taxes and subsidies, regulation \\
Equity objective & Subsidies, provision \\
Redistribution & Provision, subsidies \\
Merit goods & Regulation, provision \\
\hline \hline
\end{tabular}




\section{Bibliography}

Arrow, K.J. 1951a. Social Choice and Individual Values. New York Wiley.

Arrow, K.J. 1951b. An extension of the basic theorem of classical welfare economics. In Proceedings of the Second Berkeley Symposium on Mathematical Studies and Probability, ed. J. Neyman, 507-532. Berkeley: University of California Press.

Arrow, K. J., and Lind, R. C. 1970. "Uncertainty and the Evaluation of Public Investment Decisions" American Economic Review 60: 364-78.

Belli, P., Anderson, J., Barnum, H., Dixon, J., and Tan, .-P. 1996. Handbook on Economic Analysis of Investment Operations. Processed.

Coase, R. "The Problem of Social Cost." Journal of Law and Economic, 60: 1-44.

Cowling, K., and Mueller, D. C. 1978 "The Social Costs of Monopoly Power. Economic Journal 88: $727-48$.

Debreu, G. 1959. The Theory of Value. New York: Wiley, New York.

DiLorenzo, T. J., and Robinson, R. 1982. "Managerial Objectives Subject to Political Market Constraints: Electric Utilities in the U.S.," Journal of Public Economics 13: 259-76.

Dixon, J. A., Scura, L. F., Carpenter, R. A., and Sherman, P.B, 1994 Economic Analysis of Environmental Impact. 2d ed. London: Earthscan Publications.

Ferguson, P. 1988. Industrial Economics: Issues and Perspectives. London: Macmillan.

Greenwald, B. C., and Stiglitz, J. E. 1986. "Externalities in Economies with Imperfect Information and Incomplete Markets." Quarterly Journal of Economics 101: 229-64.

Galal, A., and Shirley, M. 1995. Bureaucrats in Business: The Economics and Politics of Government Ownership World Bank Policy Research Report. New York: Oxford

University Press.

Hammer, J. S. 1996. Economic Analysis for Health Projects. Policy Research Working Paper 1611. Washington, D.C.: World Bank.

Harberger, A. C. 1954. "Monopoly and Resource Allocation." American Economic Review 44: 77-87.

Harberger, A. C., 1968. The discount rate in public investment evaluation (Conference Proceedings of the Committee on the Economics of Water Resources Development, Waste Agricultural Economics Research Council, Report no. 17, Denver, CO. 
Hufschmidt, M. M., James, D. E., Meister, A. D., Bower, B. T., and Dixon, J. A. 1988. Environment, Natural Systems, and Development: An Economic Evaluation Guide. Baltimore: The Johns Hopkins University Press.

Lal, D. 1994. The Role of the Public and Private Sectors in Health Financing. HRO Working Papers HROWP 33. Washington, D.C.: World Bank.

Moore, T. G. 1970. "The Effectiveness of Regulation of Electric Utility Prices. "Southern Economic Journal 36: 365-75.

Peltzman, S. 1971. "Pricing in Public and Private Enterprises: Electric Utilities in the United Sates," Journal of Law and Economics 14: 109-47.

Sandmo, A. and Dreze, J. H.1971. "Discount Rates for Public Investment in Closed and Open Economies." Economica 38: 395-412

Sjaastad, L. A., and Wisecarver, D. L. 1977. "The Social Cost of Public Finance." Journal of Political Economics, 85: 513-547

Smith, Adam. 1937 The Wealth of Nations. New York: Modern Library (originally published in 1776).

Stiglitz, J. E. 1984. Pecuniary and Market Mediated Externalities: Towards a General Theory of the Welfare Economics of Economies with Imperfect Information and Incomplete Markets. National Bureau of Economic Research, Working Paper Series No. 1304. Washington, D.C.

Stiglitz, J. E. 1988. Economics of the Public Sector. New York: W.W. Norton

Stiglitz, J، E. 1994. Whither Socialism? Cambridge, MA: The MIT Press

Stiglitz, J. E. 1996. "Some Lessons from the East Asian Miracle." World Bank Research Observer 11: 151-177.

Varian, H.R. 1987. Intermediate Microeconomics, a Modern Approach. 3d ed. New York: W.W. Norton.

Viscusi, W. K. Vernon, J. M. and Harrington, J. E. 1996. Economics of Regulation and Antitrust. 2d ed. Cambridge, MA:. The MIT Press. 


\section{Policy Research Working Paper Series}

Title

WPS1815 Unfair Trade? Empirical Evidence in World Commodity Markets Over the Past 25 Years

WPS1816 Returns to Regionalism: An Evaluation of Nontraditional Gains from Regional Trade Agreements

WPS1817 Should Core Labor Standards Be Imposed through International Trade Policy?

WPS1818 What Affects the Russian Regional Governments' Propensity to Subsidize?

WPS1819 The Argentine Pension Reform and Its Relevance for Eastern Europe

WPS1820 Private Pension Funds in Argentina's New Integrated Pension System

WPS1821 The "IPO-Plus": A New Approach to Privatization

WPS1822 Intergovernmental Fiscal Transfers in Nine Countries: Lessons for Developing Countries

WPS1823 Antidumping in LaW and Practice

WPS1824 Winners and Losers from Utility Privatization in Argentina: Lessons from a General Equilibrium Model

WPS1825 Current Accounts in Debtor and Creditor Countries

WPS1826 Standards and Conformity Assessment as Nontariff Barriers to Trade

WPS1827 The Determinants of Agricultural Production: A Cross-Country Analysis
Author

Jacques Morisset

Raquel Fernandez

Keith E. Maskus

ev Freinkman

Michael Haney

Dimitri Vittas

Dimitri Vittas

Itzhak Goldberg

Gregory Jedrzejczak

Michael Fuchs

Jun $\mathrm{Ma}$

Raj Krishna

Omar Chisari

Antonio Estache

Carlos Romero

Aart Kraay

Jaume Ventura

Sherry M. Stephenson

Yair Mundlak

Don Larson

Ritz Butzer
Date

August 1997

August 1997

J. Ngaine 37947

September 1997

C. Ima 35856

Contact

for paper

N. Busjeet 33997

August 1997

J. Ngaine 37947

August 1997

N. Campos 38541

August 1997

P. Infante

37642

August 1997

P. Infante

37642

August 1997 I. Goldberg 36289

A. Bobbio

81518

September 1997

T. Malone 37198

September 1997

R. Martin 39026

September 1997

M. Pateña 39515

September 1997

P. Kokila 33716
September 1997 


\section{Policy Research Working Paper Series}

Title

WPS1828 The Determinants of Banking Crises: Evidence from Developed and Developing Countries

WPS1829 Economic Reform and progress in Latin America and the Caribbean

WPS1830 Private Ownership and Corporate Performance: Some Lessons from Transition Economies

Author

Asli Demirgüç-Kunt Enrica Detragiache

Norman Loayza Luisa Palacios

Roman Frydman Cheryl W. Gray Marek Hessel

Andrzej Rapaczynski

WPS1831 How Trade Patterns and Technology Wolfgang Keller Flows Affect Productivity Growth

WPS1832 Pension Reform in Bolivia: Innovative Hermann von Gersdorff Solutions to Common Problems

WPS1833 Cost Recovery and Pricing of Payment Services
David B. Humphrey

Robert H. Keppler

Fernando Montes-Negret
Contact

for paper

September 1997

P. Sintim-Aboagye 38526

September 1997

E. Khine 37471

September 1997

B. Moore 38526

September 1997 J. Ngaine 37947

September 1997

C. Pavlak 82099

October 1997

T. Ishibe 38968 